\title{
FROM MANAGING BEES TO SCHEDULING LIFE VIA DAY SIGNS: THE LOG HIVE AS A WINDOW FOR COMMUNICATION IN PRE-HISPANIC MAYA SOCIETY
}

\author{
DO MANEJO DE ABELHAS ATÉ A ORGANIZAÇÃO DA VIDA ATRAVÉS DOS SÍMBOLOS DO DIA; A \\ COLMEIA-TORA COMO UMA VIA DE COMUNICAÇÃO NA SOCIEDADE MAIA PRÉ-HISPÂNICA
}

\author{
Dirk KOEDAM*
}

Federal University of the Rural Semi-arid Region, Department of Animal Sciences, Avenida Francisco Mota 572, CEP: 59625-900, Mossoró, RN, Brazil *dkoedam1@gmail.com

\begin{abstract}
Mayas from the pre-Hispanic period documented important facts and life experiences via a writing system consisting of hieroglyphs. To timetable these events, they used time units such as the so-called day signs, whose origins are largely unknown. Classic Maya civilization included a tradition of keeping native stingless bees in horizontally oriented, hollowed-out logs for the production of honey and wax. The legacy and value of this stingless-bee keeping, also called meliponiculture, can be found in their culture and religion. The most commonly kept species was Melipona beecheii, which the Mayas knew by the name of Xunan-kab. The principal way for Mayan beekeepers to access nest interiors and extract honey and wax was via the ends of the rustic log hives. Here I argue that the day signs Imix, Kib', Kab'an, Kawak and Ajaw represent cross sections of log hives that are visible when opened at their sides. The signs' interiors reflect extant but stylized bee nest elements that are important to beekeeping, such as food stocks, brood content, adult bees, and nest entrances. Similar to all other day signs and nearly all variants, their roundish, outer frames imitate a hollow log's solid wall. In those cases where numerous hives were densely stacked together in bee sheds, Maya beekeeping must have become more complex in its organization. To tackle increasing complexity in bee management and sustain colony growth and optimize honey and wax production, Mayan beekeepers likely administered their work based on written figures related to beekeeping details. The five day signs were probably derived from a mnemonic system that originally was intended to identify individual log hives, to keep records of colonies and to share information with others involved in this activity.
\end{abstract}

KEYWORDS: Classic Maya civilization; day signs; meliponiculture; log hive cross section; hive administration; scheduling life.

\section{RESUMO}

Os maias do período pré-hispânico documentaram fatos importantes e experiências da vida através de um sistema escrito de hieróglifos. Para agenda-los, eles usaram unidades de tempo como os chamados símbolos do dia, cujas origens são em grande parte desconhecidas. A civilização maia clássica incluía a tradição de criar abelhas sem ferrão nativas em toras ocas, posicionadas horizontalmente para a produção de mel e cera. O legado e valor deste manejo de abelhas sem ferrão, também chamada meliponicultura, podem ser encontrados na sua cultura e religião. A espécie nativa mais criada era Melipona beecheii, conhecida pelos maias com o nome de Xunan-kab. Para os meliponicultores maias a principal maneira para acessar os interiores dos ninhos e extrair mel e cera era pelas laterais das colmeias rústicas. Aqui, eu argumento que os símbolos dos dias Imix, Kib', Kab'an, Kawak and Ajaw representam cortes transversais das colmeias-toras quando observadas das suas laterais abertas. As partes internas destes símbolos refletem elementos existentes, porém estilizados, do ninho das abelhas, importantes para a meliponicultura como estoques de alimento, cria, abelhas adultas, e entradas do ninho. Igual a todos os outros símbolos do dia e quase todas as variações, seus contornos arredondados imitam a parede sólida dos troncos ocos. Nos casos em que muitas colmeias-toras eram empilhadas juntas densamente em abrigos de abelhas, a meliponicultura maia teria se tornado mais complexa na sua organização. Para enfrentar uma crescente complexidade no manejo das abelhas e sustentar o desenvolvimento colonial e otimizar a produção de mel e cera, alguns meliponicultores provavelmente implementaram administrações baseadas no uso de figuras escritas relacionadas com detalhes do manejo de abelhas. Os cinco símbolos do dia talvez sejam derivados de tal sistema mnemônico cuja função originalmente era de identificar colmeias individuais, manter registros de colônias e compartilhar informações com outros envolvidos nesta atividade.

PALAVRAS-CHAVE: Civilização maia clássica; símbolos do dia; meliponicultura; corte transversal da colmeiatora; administração de colmeias; programar a vida. 


\section{The tradition of Maya beekeeping, and associated depictions}

Classic Maya civilization comprises the period from ca. 2000 BC to AD 1539, when it was ended by the Spanish conquest (THOMPSON, 1950; HAMMOND et al., 1976). The ancient Mayas cultivated staple crops such as maize, beans and squash, and supplemented their diets with fruit and root plants, including chili peppers, cacao and manioc (LENTZ, 1999). The keeping of native bees was an important part of their culture; the Mayas produced honey and wax both for their own use and for trade (see SCHWARZ, 1948). For example, honey was used to brew a traditional alcoholic beverage (LANDA, 1566; WEAVER and WEAVER, 1981), while wax was used as a molding material in the manufacture of gold ornaments (SAVILLE, 1920). The Mayas respected bees and worshipped bee gods during special rituals (MARTÍNEZ, 1938; WEAVER and WEAVER, 1981). During the Postclassic period (from ca. AD 900), beekeeping on the Yucatan Peninsula prospered, with bee stands holding numerous hives (see KENT, 1984). Nowadays, traditional Maya beekeeping is in serious decline (VILLANUEVA et al., 2005).

Maya hieroglyphic script is based on more than one ancient language, and it has been recovered from various different substrates, including stone, native paper and ceramics (see KETTUNEN and HELMKE, 2005). An important source of information on Mesoamerican pre-Hispanic culture and religion is the so-called Maya codices. These are folded sheets of bark paper with hieroglyphic texts and pictures, which likely date from the Postclassic period (see VAIL, 2000). Mayan scribes depicted a variety of animals with various degrees of reality and levels of elaboration, including insects such as bees and their pot honey (TOZZER and ALLEN, 1910). The Madrid Codex includes several pages dedicated to the practice of beekeeping and its rituals (VAIL, 1994). Among the various figures related to beekeeping, the drawings of headless queen bees stand out. Headless queen bees would originally have represented lost colonies (CAPPAS E SOUSA, 1995) and consequently stood for a harvest of valued bee products in peril. Recently, I made the case that scribes from the Classic period (AD 250900) applied the same, natural phenomenon of a headless queen bee as a model for the three-sided or partially visible quatrefoil glyph they sculpted (KOEDAM, 2018). This glyph was catalogued as affix T173 (THOMPSON, 1962) and is one of several zero characters, including shell-like images and head and full-figure variants that the Mayas used in inscriptions and manuscripts (see BLUME, 2011).

To timetable certain happenings, such as ritual cycles, dynastic events and astronomical series, the ancient Mayas used various categories of time units such as the so-called day and month signs (BRINTON, 1893). What daily-life subjects served as models for these time units is far from clear. TOZZER and ALLEN (1910) considered the interior structures of the day sign Kawak to symbolize "honey combs". THOMPSON (1950) concluded that the sign Kib' was the day of the Bacabs, the patrons of beekeeping. CAPPAS E SOUSA $(1995,1996)$ was the first to discover and comment upon the up-till-then largely ignored, close relationship between Maya bee husbandry and several of their glyphs and other drawings, including some day signs. Here, I argue that the full depictions of five day signs, just as the overall configuration of all 20, reflect the way Mayan beekeepers would have visualized a nest inside a horizontal $\log$ hive each time they exposed its ends. As some practices of Maya beekeeping grew larger, the beekeepers had to deal with increasing organizational complexity. Some of them did so by developing figures related to beekeeping details, in order to improve production. The five day signs were apparently derived from such administrational activity.

\section{Melipona beecheii hived in logs and Maya beekeeping expertise}

Beekeeping practice aims at exploiting nests during consecutive years. Mayan people from the pre-Hispanic period kept bees in horizontally oriented, hollowed-out logs originating from forest trees (see CRANE and GRAHAM, 1985; CRANE, 1998). These rustic log hives were either hanging individually under the eaves of houses or stacked one on top of the other against a slanted support structure made of stones or wood (Figure 1; HUBER, 1839; SCHWARZ, 1948). Both the extremes of these logs were sealed off by round, wooden or stone stoppers, also called panuchos, whose diameters correlate with the breadths of the individual trunks to make them fit (see CRANE and GRAHAM, 1985). In the case a natural nest opening was absent, beekeepers punctured a hole somewhere in the middle of the trunk large enough for the bees to leave and enter. The use of ceramic cylinders, imitating wooden 
logs, has been documented (HUBER, 1839; see also ŹRAŁKA et al., 2018).

Although several different indigenous social bee species occur in what once was Maya territory (AYALA, 1999), beekeepers principally tended the species Melipona beecheii Bennett and Scaptotrigona spp. such as S. mexicana (Insecta, Hymenoptera, Meliponini) (see SCHWARZ, 1948). The ancient Mayas named M. beecheii Xunan-kab; it is among the larger representatives of the so-called stingless honey bees. This group of bees is found only in tropical and subtropical regions of the world; the females have atrophied stings (ROUBIK, 1989). Like the better-known Apis honey bee (Insecta, Hymenoptera, Apidae), they live in permanent colonies, have a single, active queen and multiply by swarming (MICHENER, 1974; SAKAGAMI, 1982). In contrast with Apis spp., stingless bee colonies are in general smaller, grow at a slower pace and produce less honey. Their nests have inconspicuous entrances and, although worker bees of some species defend their nest by fierce biting, stingless-bee keeping or meliponiculture is uncomplicated and safe, and yields highly-valued honey (CORTOPASSILAURINO et al., 2006).

At first sight, the keeping of bees under semi-natural conditions in short lengths of tree trunks appears plain and primitive. Nevertheless, history has proven that honey bee colonies housed in horizontally oriented logs or clay cylinders generally do well and thrive (CRANE, 1983). Moreover, various details demonstrate that the ancient Mayas' custom of cultivating bees in logs should be considered advanced.

Stingless bees suffer from a number of predators and parasites (ROUBIK, 1989). One of the parasites feared most by beekeepers is a scuttle or phorid fly (Phoridae), which not only can be lethal for an infested colony, but also has the potential to contaminate nearby colonies (CONTRERA et al., 2008). Out of necessity, stingless-bee keepers nowadays use various techniques to prevent or reduce such infestations (OLIVEIRA et al., 2013). Excavations of stone hive disk stoppers and Spanish postconquest reports revealed high densities of hives in bee sheds at different locations on the Yucatan Peninsula and beyond (CRANE and GRAHAM, 1985); concentrations of up to a couple of thousand hives were probably not uncommon (OVIEDA Y VALDÉS, 1851-1853). The existence of such large groupings of hives by itself tells us that the ancient Mayas, along with the capability to confront other natural threats to their bee husbandry, must have mastered methods to thwart phorid flies.

From text and images in the Madrid Codex it seems that the Mayas not only hunted for feral bee nests, but that they were also capable of artificially multiplying nests to augment their stock of colonies (CAPPAS E SOUSA, 1995; JONG, 1999). In apicultural terminology such a multiplication technique is also called 'making increase' or 'colony splitting'. This technique is still commonly used among present-day Mayan beekeepers (REDFIELD and VILLA ROJAS, 1934; WEAVER and WEAVER, 1981) and is straightforward in execution. In line with the natural course of reproductive behavior during incidences of stingless bee swarming, the old but active queen is not killed but only partially replaced by a young, virgin queen (e.g. INOUE et al., 1984; VEEN and SOMMEIJER, 2000). It is supposed that such transitions in queen caste make-up, induced by Mayan beekeepers when splitting colonies of M. beecheii, underlie the textual use of the figure T173 as a part of the so-called "half-period glyph" (KOEDAM, 2018).

The above description of some management details shows that the ancient Mayas were probably skilled at keeping native meliponine bees.

\section{Nest characteristics of $M$. beecheii; their natural organization and structure}

As do most other wild stingless bees, $M$. beecheii makes its nests in the hollows of living trees (MICHENER, 1974). From such permanent locations, forager bees daily search the surroundings for pollen and nectar that they bring back to the nest and store separately in large, similar-sized food pots (Figure 6a, c; BIESMEIJER, 1997; MICHENER, 2000; ROUBIK, 2006). Hive bees use part of these stores to provide food for the brood (SAKAGAMI, 1982). Other intranidal tasks involve nest defense, wax production and construction of nest components, such as food pots and the smaller brood cells. As a rule, the queen is the only colony member active in the laying of fertile, diploid eggs (MICHENER, 1974).

Similar to other species of the genus Melipona, M. beecheii worker bees construct waxen brood 
cells that are orderly and hexagonally packed in horizontal, rounded combs (Figure 6c). In the space immediately surrounding the brood, workers build clusters of large waxen pots to store their food (SAKAGAMI, 1982). The cells of new brood combs are built on top of older combs as long as space permits. Old brood cells are demolished soon after individuals have emerged and the wax is reused. In this way, the brood area is characterized by a set of vertically stacked combs that are recycled through time and space by the constant building and break down of individual brood cells. Similar to the connections between the successive brood combs, the food pot clusters are connected to the brood and to the inner side of the nest border wall by means of many small short pillars made out of wax (Figure $6 c)$.

Stingless bee nests remain separated from the outside world either by a pre-existing partition like the walls of a natural cavity, or by a firm, fully bee-made structure (ROUBIK, 2006). In order to avoid unwanted invasions, the restoring of flaws in the nests' outer wall is one of a set of workers' tasks that probably always has priority. The only permanent link for nest inhabitants to the external world consists of a small nest orifice. Melipona beecheii has a one bee-size nest opening with an enclosing structure, made of mud, with disrupted margins of peripheral dots and radial stripes (Figure 2c; see BIESMEIJER et al., 2005). The opening itself is blocked from intruders by a guard bee that allows only resident individuals to pass. Non-resident individuals, whether con- or heterospecific, that try to enter are attacked, immobilized and/or killed. In the cases of imminent danger and during night hours, $M$. beecheii bees can block their nest entrance by constructing a temporary mesh barrier made out of wax and resin (COHN, 2005).

\subsection{Monitoring stingless bees in hives; intranidal information from the outside}

A wide range of biotic and abiotic factors, including handling by beekeepers, affect colony wellbeing (NOGUEIRA-NETO, 1997). For this reason, and because stingless bee nests are relatively small and vulnerable (ROUBIK, 1989; see also section 5.1), the conditions of their colonies need to be checked regularly. To obtain an impression of a colony's condition and performance in a simple way, in general beekeepers have several non-intrusive options at hand when they keep their bees in hives, including those made from hollow logs. One such way is to lift the hive a little and roughly estimate its weight. Independently hanging logs can be checked readily in this fashion. However, a common method in which the ancient Mayas stacked log hives one on top of the other with the help of an artificial support structure (Figure 1; SCHWARZ, 1948; CRANE, 1998) makes the hefting of hives, as well as intrusive management activities, difficult to perform.

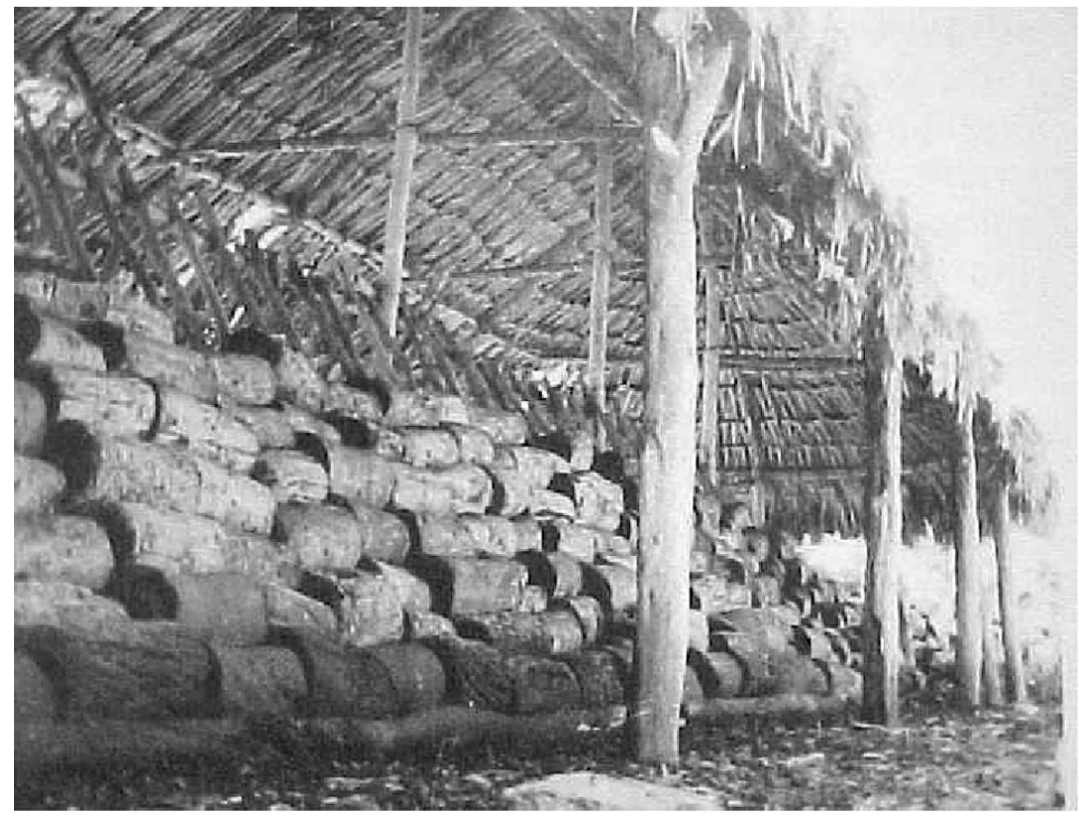

Figure 1: View of one of two sides of a traditional Maya meliponary from the beginning of the 20th century with several hundred hives (photo courtesy of Felipe Martínez López)

An indication of general bee stock health can also be determined from the instances in which 
bees fly in an agitated manner towards nearby people and try to bite them (Figure 4b). This collective, natural form of aerial defensiveness can be provoked by opening hives or in any other way that nests are disturbed (NOGUEIRA-NETO, 1997; ROUBIK, 2006). In such cases, the person causing the disturbance may end up with many bees buzzing around his head, while various will cling strongly to his hairs (Figure 4b). However, the bees' overt aggressiveness is non-lethal to humans and large animals, and is more common among the Trigona than among the Melipona bees (COUVILLON et al., 2007). People may become anxious and panic when they are unfamiliar with this defensive response of meliponine bees. In contrast to weak colonies, worker bees from strong colonies are generally more defensive and react with more vigor (personal observation). However, intraspecific variation in levels of nest defensiveness has so far received little attention. Ancient Mayan beekeepers may or may not have used clues from aerial defense activity in their evaluation of colony strength. However, they surely must have noticed this conduct, especially when many hives were kept in one location.

\subsection{Unsealing log hives, and its drawbacks}

To momentarily access the interior of a log hive in a convenient manner in order to either do a survey or to harvest honey, a beekeeper has to remove one or both of the hive's lateral plugs (Figure 2a). This unplugging is also a way to visualize the number of food pots and estimate colony population size. By maneuvering only the lateral nest plugs, the overall structure of the log hive remains intact, in this way guaranteeing the permanency of the colony that it accommodates. The constant threat of an invasion by other bees, ants and phorid flies makes careful sealing of the hive structure imperative.

Opening a hive can also be a means to examine the queen and the brood (Figure 4a). The advantage for beekeepers to make sure there is an egg-laying queen and evaluate its reproductive vigor is because this helps to guarantee overall colony maintenance and reproduction. Furthermore, quantifying existing brood and the stages of its development informs a beekeeper in at least two ways about a colony's condition. Firstly, the amount of brood is the outcome of the collective labor of both the egg-laying queen and the nest-building and nursing workers. Secondly, a visual assessment of the brood combs also discloses the potential future performance of a colony through its ability to generate fresh workers that will gather nectar and pollen in the months to come.

Probably the most valued bee product in beekeeping is honey (CRANE, 1983; CORTOPASSILAURINO et al., 2006); it requires attention and skill to determine the optimum date of its harvest. During the flowering season, worker bees will continue to store honey and pollen until all the hive space has been fully exploited. Saturation of the available space is the ideal moment for beekeepers to open the hive and take out the honey; a premature harvest renders less honey, whereas a harvest overdue increases the chance that a colony reproduces by swarming, in which case the bee owner will permanently lose a significant part of the population of that colony.

Leaving brood and the active queen unaffected while harvesting honey increases the chances of colony survival (see also MAIA et al., 2015). The presence of brood centered in a horizontally oriented $\log$, nearly in front of the nest entrance, is in this case the most practical situation; the bees would accumulate food on both the left as well as on the right hand side of the brood (Figure 6a) and so facilitate a beekeeper's access to and manipulation of these stocks. The presence of food pots on both ends, though, means that beekeepers have to open both ends of a log hive to reach all the honey.

To liberate access to the comb region, the natural barrier of food pots often has to be removed first. Later in this paper (section 4.4), another intrusive but sustainable technique is explained that aims to exclusively collect combs, but does not follow the route via the ends of logs. However, for now this method is only known from current Maya beekeeping. 


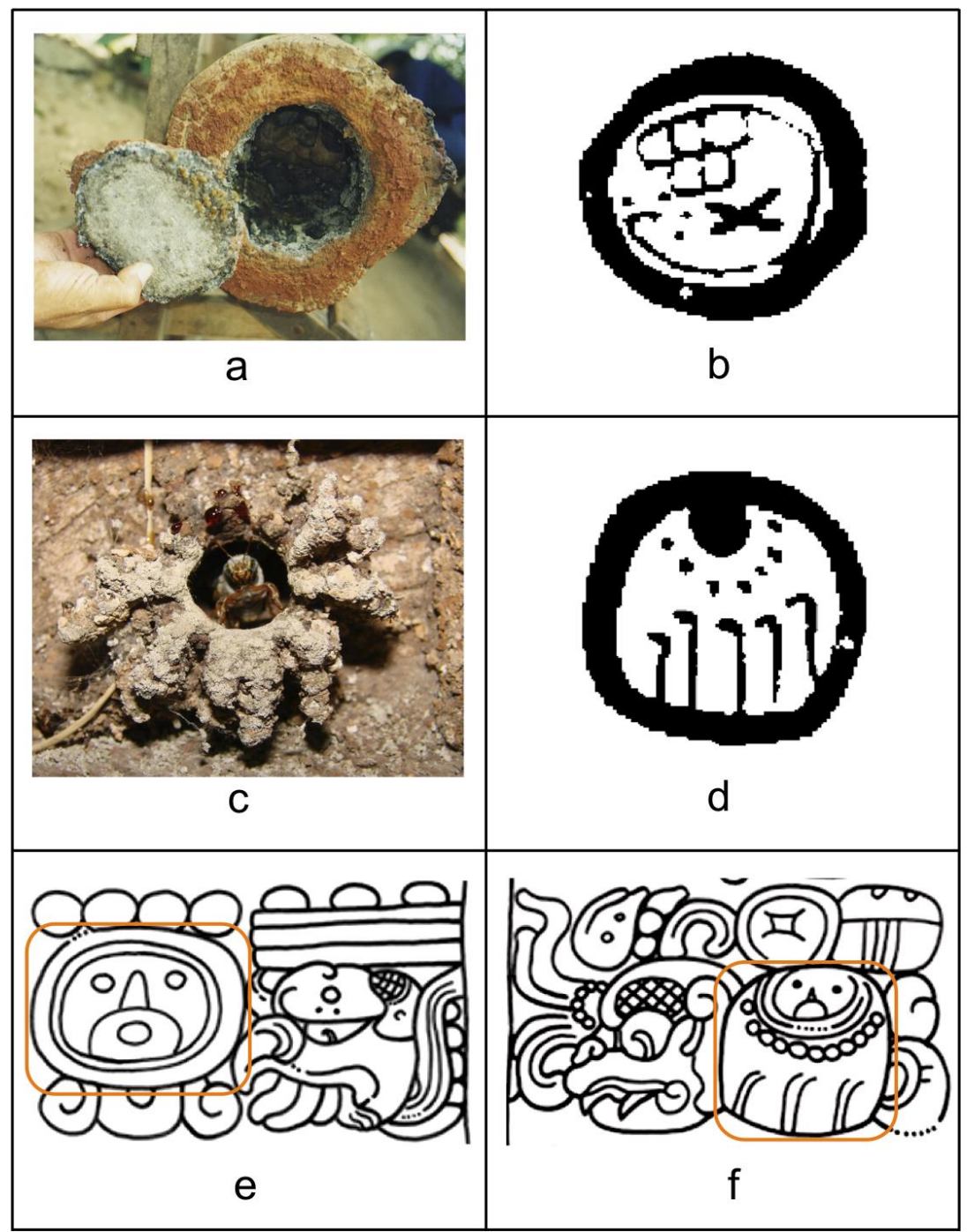

Figure 2: a. View of an opened end of a log hive while its stopper or panucho is held next to it (photo courtesy of Adalberto Aguilar Coronado), b. The day sign Kawak showing a cluster of honey pots, Madrid Codex, p. 106, c. An entrance of a Melipona beecheii nest with the characteristic bee-made, peripheral dots and radial stripes, d. The day sign Imix, representing a stylized nest entrance and its ornamentation, Madrid Codex, p. 106, e. The day sign Ajaw (orange sector) representing a full face of the nest's sentinel bee, Copan Stela A, west side (SCHELE DRAWING COLLECTION), f. The day sign Imix (orange sector) with an infix of a small Ajaw showing the sentinel bee blocking the actual nest opening, Copan Stela A, west side (SCHELE DRAWING COLLECTION)

The act of opening stingless-bee hives has several disadvantages, and this is especially true for unstable, rolling-prone logs (see also KOEDAM, in prep.). Firstly, bees of an opened hive get agitated (see section 3.1), and this temporarily disturbs colony functioning and interrupts brood production. Concurrently, it allows parasites such as the aforementioned, potentially colony-lethal, small scuttle or phorid flies to enter and harm the exposed nest (CONTRERA et al., 2008). An even more serious problem is that once phorid flies have invaded a nest, they will use it as a substrate to rapidly propagate a dangerous infestation that can affect neighboring hives. An extra, complicating factor here is that the inevitable human-generated damage of brood combs (see section 4.2) can seriously boost phorid fly plagues.

The reinstallation of the hive-plug disks is a rather laborious and time-consuming procedure when compared with the closing of modern beehives (for traditional Maya beekeeping: JONG, 1999; WEAVER and WEAVER, 1981). Although simple in execution, the procedure should be carried out with attention because a badly sealed hive will become an easy target for parasites to attack and invade. In addition, as a response to the human process of putting the disks in place and closing the cracks with mud mortar, a part of the working force of the hive bees will redirect itself to assist in the covering of small imperfections in the hive wall that have remained. Task switching has been documented to occur 
in various groups of social insects, such as ants and Apis honey bees (e.g. GORDON, 1989; JOHNSON, 2002). Although its impact is temporary, the switching of $M$. beecheii worker bees to urgent repair duties occurs at the cost of normal food foraging and processing, and so would be against the primary interest of the beekeeper.

Ancient Mayan beekeepers may not have been fully conscious of each cost arising from the handling of colonies when they opened hives via the logs' ends. They also may not have known in what way the various aspects of such processes could negatively impact their colonies. However, any experienced Mayan beekeeper would have preferred to monitor colonies and their development by leaving the hives untouched as much as possible.

\section{The concept of the cross-sectioned log beehive in Maya script}

The Mayas have been keeping their main bee species, Melipona beecheii, within log cavities probably for many centuries (CRANE and GRAHAM, 1985; KOEDAM, 2018; see also ŹRAŁKA et al., 2018). As a result, their principal interaction with these native bees was concentrated on the logs' ends. Each time they exposed the ends of an inhabited log hive to gain access to its inner space, they would view the nest within it from that specific angle. For this reason, I suggest that the space inside $\log$ hives not only defined the bees' domain of residence, but also became a framework of reference for the Mayas in developing mnemonic figures. Here, I apply this frame of reference to Maya day signs and discuss for some of these glyphs what parts of bee nests Mayan beekeepers originally intended to visualize.

\subsection{The day signs Kawak, Imix and Ajaw, and their relations to log-hived bees}

The Maya day signs comprise a group of 20 different glyphs that served to count time in the sacred calendar of the 260-day Tzolk'in cycle (MORLEY, 1915; MALMSTROM, 1973). This system served to record dates by the permutation of 13 numbers with the 20 day signs in an unbroken sequence. One of these signs is Kawak (Figure 2b), which is the penultimate of the 20-day sequence (BRINTON, 1893). THOMPSON (1950) concluded that this day sign stands for rain and storm. Prior to that, Kawak's main element and its spatial orientation rendered it its commonly applied description as "cloud-balls" (see BRINTON, 1894). According to TOZZER and ALLEN (1910), however, this glyph element shows a cluster of honey pots. Here I add that the complete Kawak image is essentially a look through or crosssectioned view of a log hive when opened from its side, in which the stylized cluster of honey pots is surrounded by the log's roundish wall (Figure 2a, b). For some reason, though, the pots seem to be hanging upside down. From an epigraphical point of view, the depicted honey pot cluster can be considered as a mere infix. Still, this same set of honey pots is also an inseparable part of an almost literal copy of the interior of an inhabited log beehive that one visualizes when one removes the side disks.

Another day sign having a supposed beekeeping background is the first sign of the 20-day sequence, named Imix (Figure 2d; BRINTON, 1893). According to THOMPSON (1950), this sign signifies abundance, probably of food, and represents a stylized water lily flower. CAPPAS E SOUSA (1996) instead proposed that it shows a Melipona bees' nest entrance, and that the small modifications in the variants of this glyph each express a different colony state. Here I add that in the case of this day sign, Mayan scribes must have combined the scenes of the invasive type of colony assessment with a non-invasive one; they merged a lateral view of a $\log$ 's end wall and that of a frontal view of an elaborated $M$. beecheii nest entrance into a single roundish, stylized image. On some occasions, as in variants of the day sign Kab'an (section 4.2), the nest entrance symbol is in a reduced size and incomplete form positioned against the inner, right corner of their outlines (Figures 3a-c). 


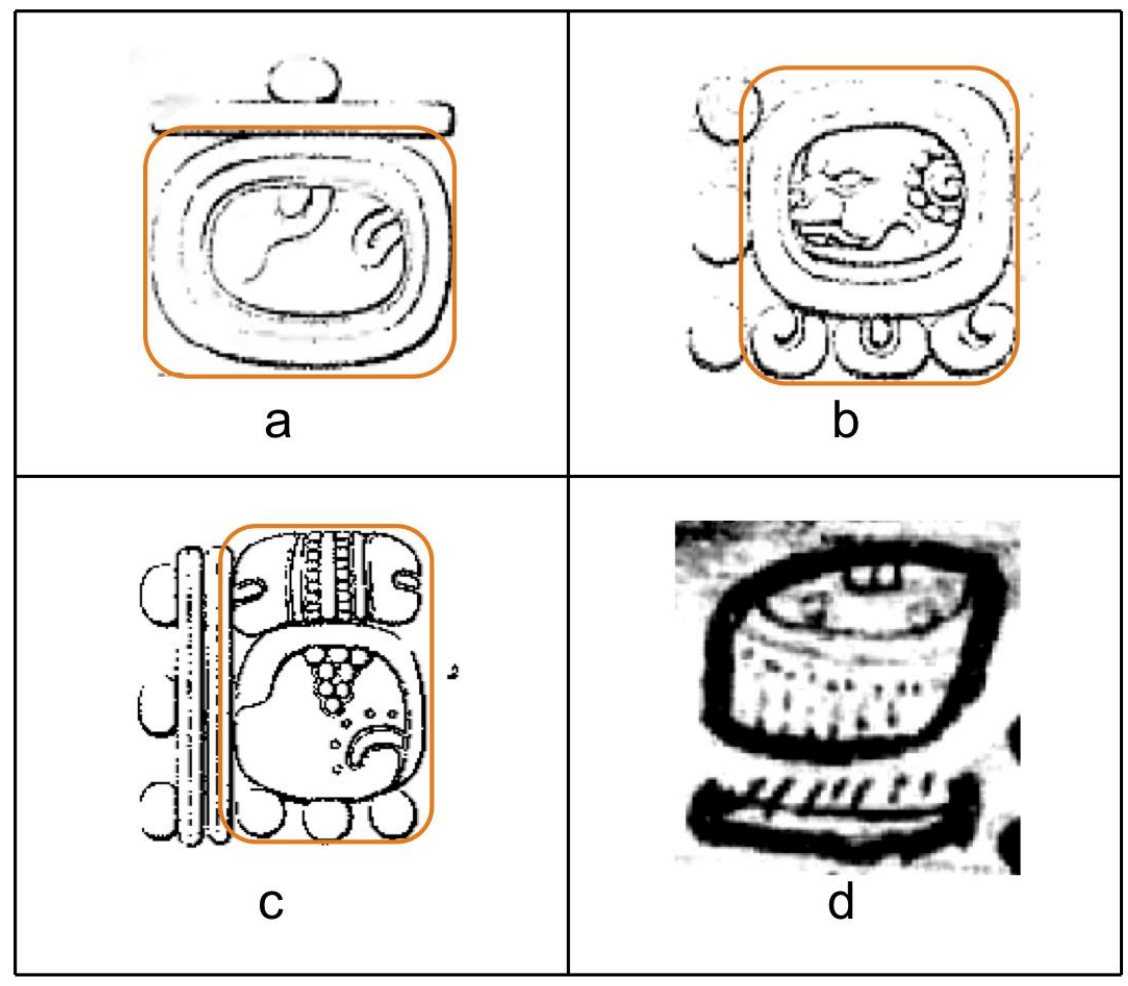

Figure 3: a. The day sign Kab'an, with, on the inner right, an element of Imix added, Copan Altar R (MAUDSLAY, 18891902), b. A head variant of the day sign $E b$, with, on the inner right, an element of Imix added, Copan Altar U, rear side (MAUDSLAY, 1889-1902), c. One of the Kawak month signs, Keh, with an infix of an element of Imix on the lower right, Copan Altar G. 2. (MAUDSLAY, 1889-1902), d. The month sign Mak, resembling an Imix image, Dresden Codex, p. 50

The sequence of the 20 Maya day signs ends with Ajaw (Figure 2e; BRINTON, 1893). According to THOMPSON (1950), it is the day of the sun god and represents a conventionalized, full face. As yet, the exact origin of the facial design is unresolved but it seems to be made up of a mixture of stylized animal and human traits. However, its occasional appearance in a small size within the day sign Imix (Figure 2f), in what probably stands for the actual nest orifice, suggests that it should be identified as a frontal view of the head of a Melipona guard bee, named Balam-kab. During the course of the 260-day calendar, the last sign of a 20-day sequence, which is Ajaw, precedes the first sign of a subsequent 20-day sequence, which is the Imix, by default (BRINTON, 1893). In other words, the images of the sentinel bee and of the ornamented nest entrance in which it resides always occur chronologically alongside each other. This would make sense because the glyphs Ajaw and Imix represent the animate and inanimate nest elements, respectively, which jointly mark the natural limit between the domain of the bees and the domain of humans, meanwhile governing the interplay between them. Resembling the design plans of Kawak and Imix, Ajaw's image of the sentinel bee's head is situated within a roundish, solid frame.

\subsection{A bee brood-based interior of the day sign Kab'an}

$K a b^{\prime}$ 'an, the $17^{\text {th }}$ day sign (Figure 5d; BRINTON, 1893), is the day of the young goddess of the earth, the moon and maize (THOMPSON, 1950). Initially, Kab'an's main feature was identified as a twisted lock of hair or "cork-screw curl" (see BRINTON, 1894) and later described as looking like a "query mark" identified as the lock of hair worn by the Goddess I in the Maya codices (THOMPSON, 1950). CAPPAS E SOUSA $(1995,1996)$ claimed that the glyph's design reveals a certain developmental phase of a bee nest and termed the dark spot as an "eye". Still, he does not explicitly mention brood nor does he provide further details about the precise element from bee biology or husbandry that Mayan beekeepers could have utilized as a source to develop this figure. I think that the day sign Kab'an highlights a specific brood phase, and I therefore will first provide supplementary information about some characteristics of bee brood and ontogeny to elaborate on CAPPAS E SOUSA's opinion.

Bees go through a complete metamorphosis and, before turning into an adult individual or 
imago, go through three developmental stages: the embryo or egg, the larva and finally the pupa (LUCAS DE OLIVEIRA, 1960; see MICHENER, 2000). Young bee brood comb is composed of cells that contain eggs or larvae. Cells from older brood combs contain pupae whose body pigmentation intensifies with age until the bees emerge as nearly fully developed adults. Unlike Apis, stingless bee individuals develop in cells that are sealed immediately after egg laying; cells remain capped until the adult bees emerge.

Different from a person working with hived Apis bees, anyone who removes brood from a stingless-bee hive or nest cannot do this without accidentally damaging a few brood cells, especially those located at the edges of combs (Figure 4c, d). Even the harvest of honey or a carefully executed invasive inspection can easily damage brood cells and unwillingly bare some of their contents. As a consequence, some cells may be partially crushed because of mechanical pressure, especially in case of younger brood. Others may have their protective waxen envelope ripped open. When older stingless bee brood cells are manipulated, cocoons can get ruptured and this will inevitably expose the pupae they contain.

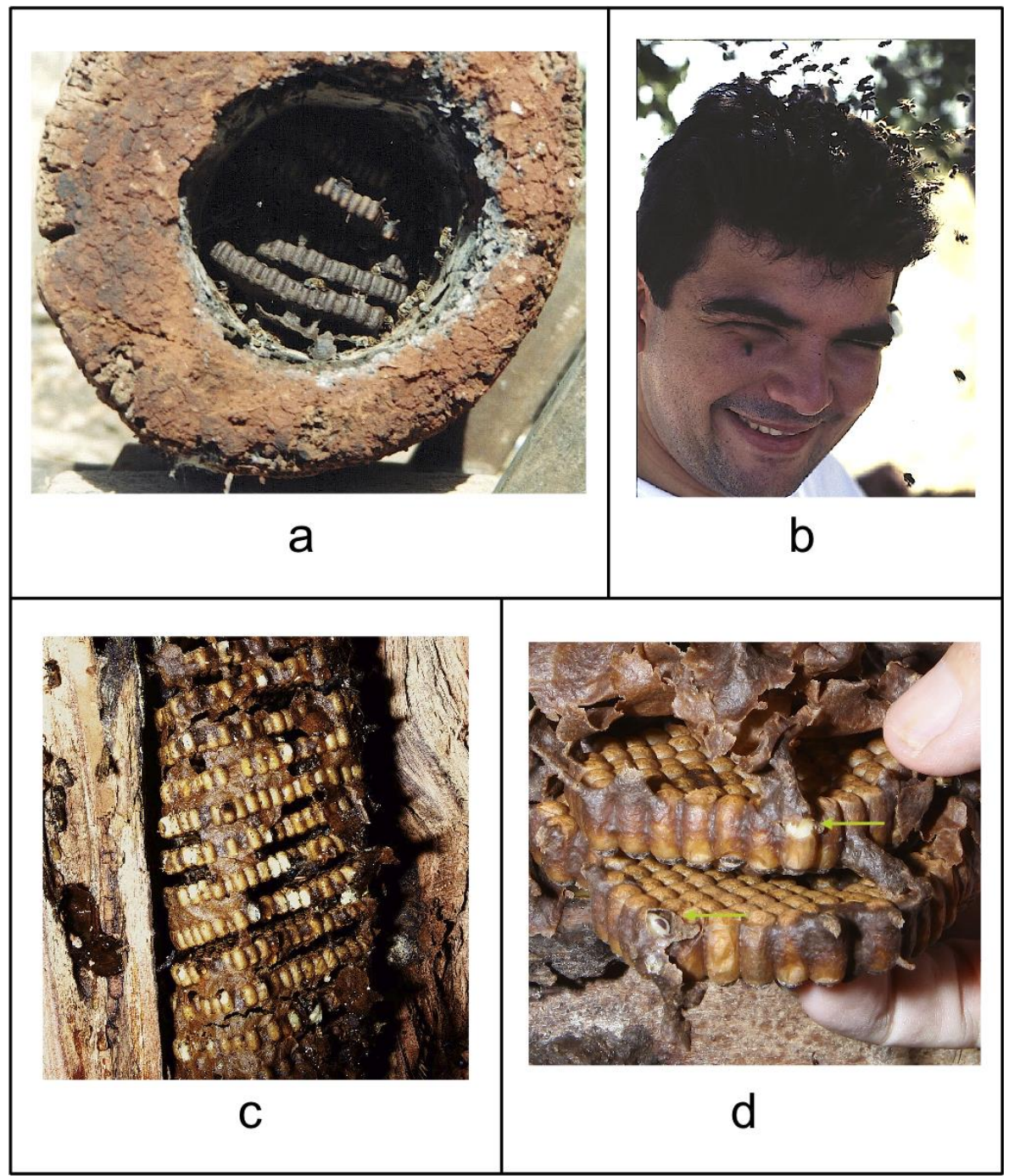

Figure 4: a. View of an opened end of a log hive with a part of the nest's horizontally oriented brood combs evident (photo courtesy of Adalberto Aguilar Coronado), b. Stingless bees attacking a person standing near a nest when it is disturbed, in order to ward off any potential threats, and with the person's hair as the focal point of their collective aggression (the person shown is Ezequiel R. Medeiros de Macêdo, a beekeeper from Jardim do Seridó, RN, Brazil), c-d. Two examples of inevitable damage to individual brood cells when (c) a tree trunk is opened to collect a feral nest (Melipona subnitida) and when (d) a set of combs is removed from a nest box (Melipona fasciculata) and the protecting wax envelope is gently removed. Both methods demonstrate how some cells, principally those located at the borders of combs, have their whitish content (pupae) exposed (arrows in d) because the cells' walls were ruptured. 


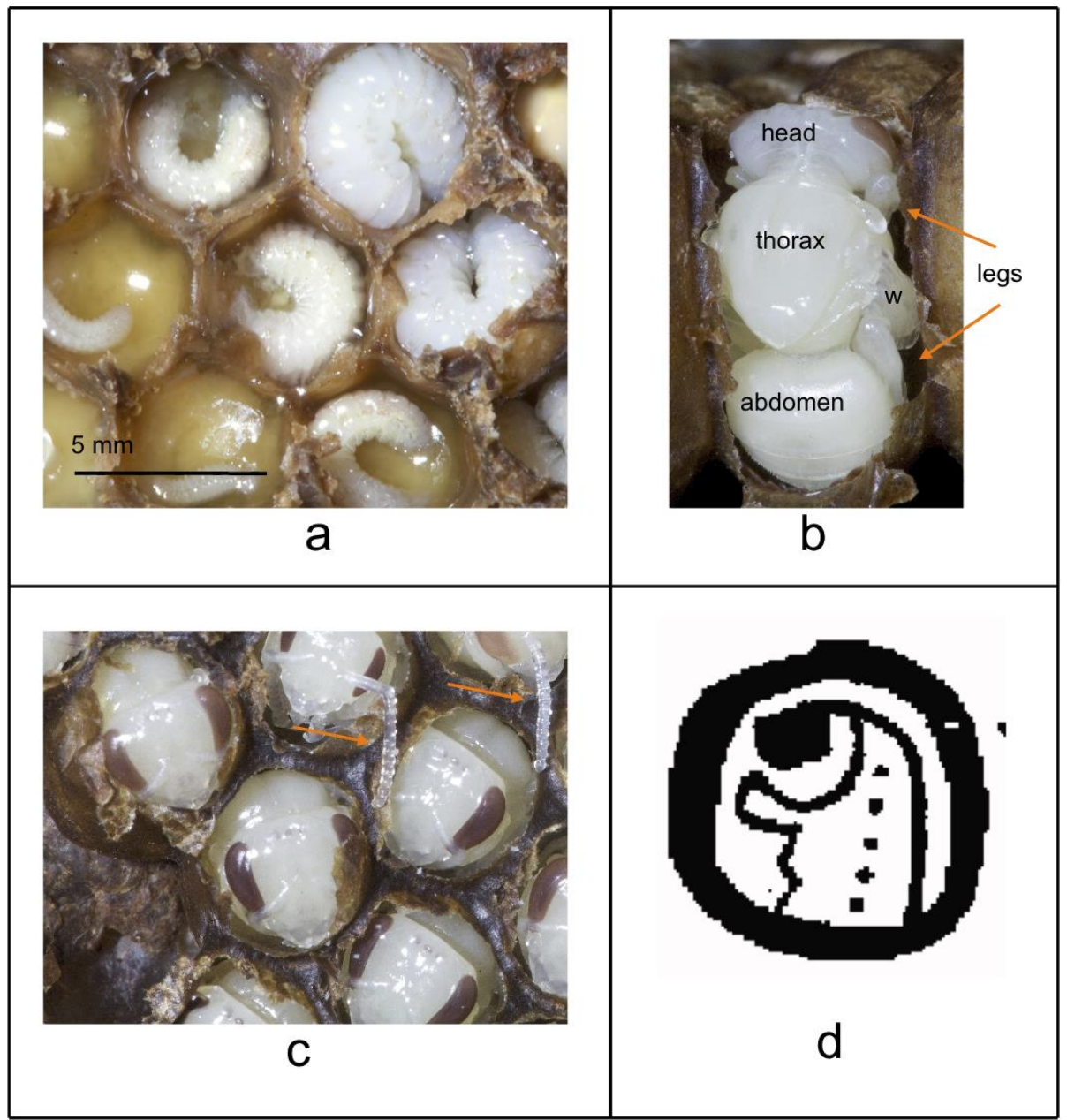

Figure 5: a. Top view of some stages of larvae of a Melipona bee (M. subnitida), each laying in its own cell from which the cap has previously been removed, showing their multi-segmented bodies, b. Dorsal view of a young pupa, showing the tripartite body plan, with the head, thorax, abdomen, and attached wings (w) and legs, c. Older brood cells with caps removed, showing the heads of pupae with their conspicuous eyes contrasting against their whitish bodies, illustrating their possible function as a model for the main element of the day sign Kab'an, (arrows indicating antennae), d. The day sign Kab'an, with the dark spot, its curvilinear trace and a vertical, dotted stroke, Madrid Codex, p. 106

Bee larvae appear as any of the worm-like, immature stages of insects that have complete metamorphosis, such as beetles, flies and butterflies (Figure 5a; BORROR et al., 1976). The external morphology of bee pupae instead reveals the first signs of typical bee characteristics, such as a tripartite body plan, being the head, thorax and abdomen respectively, and the legs and wings (Figure 5b). It is in particular the pair of dark eyes that contrasts against the motionless, whitish colored and hairless bodies, which instantly draws the attention of any observer (Figure 5c).

In my view, the day sign $K a b$ 'an represents a bee pupa, and the large dot represents the pupa's eye. That is, scribes probably transformed the conspicuous eyes of bee pupae, as beekeepers must have perceived them, literally into the eye-catching element of this figure. The curvilinear trace that starts from this dark spot downwards probably corresponds to the rest of the pupa's body, as it resembles its tripartite profile. In some Kab'an variants the dot and its short, curved line are accompanied by a separate, vertical, dotted stroke (Figure 5d). This line could depict the multi-segmented structure of the so-called flagellum-part of a pupa's antenna (Figure $5 \mathrm{c}$ ). Similar to the previously addressed day signs, the abstracted brood elements of the day sign Kab'an are surrounded by a roundish, solid border that imitates the wall of a cross-sectioned log hive.

\subsection{Are more day sign interiors beekeeping related?}

According to published reports, the interior parts of other day signs may be beekeeping related as well. For instance, CAPPAS E SOUSA (1995) believes that the ancient Mayas used the characters 
$K i b$ ' and $K^{\prime}$ 'an to specify items related to bees' wax and pollen, respectively (Figure 6d, e). According to THOMPSON (1950), Kib' means wax and is connected with the gods Bacabs, patrons of beekeeping. In this glyph, one can indeed identify the short pillars that interconnect the waxen nest structures and fix the edge of the nest to the inner side of the rigid log hive walls (Figure 6c). As pointed out by MORLEY (1915), "the line paralleling the upper part of the glyph and the short vertical lines connecting it with the outline at the top" are the only elements that Kib' figures from inscriptions and those from the codices share.

In all, a quest for beekeeping-related Maya glyphs other than the ones mentioned in this article is strongly hampered by the fact that many of them are too conceptualized to allow precise deciphering. This makes it difficult to pin down the designs of these glyphs as being related with aspects of Maya daily life with a sufficient degree of confidence. The day sign $K$ 'an illustrates this difficulty. On the other hand, $K^{\prime}$ an is related to Kib' in such a way that one is the upside-down version of the other with respect to the waxen nest elements. So, whether or not the inner artwork of this and other day signs reflect items originally meant to notify facts and happenings related to bees and their husbandry is for now impossible to confirm. However, all day signs and almost all variants appear to follow the general pattern of a picture composed of, in principal, two parts, of which one, which is the roundish, compact rim or outer frame, imitates a cross section of the wall of a log hive. Only 2.8 per cent of day sign variants $(n=355$, from THOMPSON, 1950) lack a clear outer frame. In addition, of day sign variants on Maya construction walls and monuments, 96.8 per cent have an outer frame that is continuous $(\mathrm{n}=$ 221, from THOMPSON, 1950; Figures 2e, 3a, b).

To this point, the interior parts of at least a quarter of all day signs, which are Imix, Kib', Kab'an, Kawak and Ajaw, are derived from bees and their husbandry as well; each of them seems to reflect a different, extant but stylized bee nest element. This means that every one of these signs as a whole relates to a snapshot representation of certain situations or events from beekeeping. Furthermore, the glyphs Kawak, Kab'an and Kib' are nearly factual copies of what a nest structure and organization within a trunk cavity looks like when its sides are exposed by removing the protective disks.

The thickened outlines of day sign frescos from Uaxactun, Guatemala, (ŠPOTÁK, 2017) and those of day sign inscriptions depicted in THOMPSON (1950), seem to accurately represent a log hive's wall, whereas those with the thinner, more derived outlines are the painted ones found in the Maya codices. These papers also reveal that scribes on many occasions reshaped the day signs' outer frames into more rectangular or rhomboid arrangements (Figures 3b, d, 6e; MORLEY, 1915). This may have occurred for a variety of reasons, such as ergonomic conditions and space economics together with creative skills, aesthetic conventions and design functionality. Still, considering the here-proposed exemplary role of the image and configuration of bee nests kept in logs as a template for the creation of time glyphs such as day signs, the phrase "As the glyphs often have roundish outlines, like the crosssection of a pebble, the Mayan script has been sometimes called "calculiform writing".", authored by BRINTON (1894), suddenly is much more comprehensible.

\subsection{And month signs?}

So-called month signs are a group of 18 glyphs that the ancient Mayas used to count time in the civil calendar of the 365-day Haab' cycle (MORLEY, 1915). Each of these months has a length of 20 days. Overall, their designs are more complex than day signs, also because most of them have affixes added to their main structure (Figures $3 \mathrm{c}, \mathrm{d}, 6 \mathrm{~b}$ ). Still, month and day signs also have features in common. For instance, some beekeeping elements found in day signs, like the upturned cluster of honey pots or the nest entrance, can also be encountered as parts of variants of some of the month signs, such as the four "cauac (reads as Kawak) months" Ch'en, Yax, Sak, Keh, and Mak (Figures 3c, d, 6b; see THOMPSON, 1950). In addition, several month signs have an equally roundish shape, with or without the presence of an outer frame. Conversely, when such a boundary framework is present, in three quarters of these cases it is evidently interrupted or incomplete (76\% of images on Maya construction walls and monuments, $\mathrm{n}=75$, from THOMPSON, 1950; Figures 3c, 6b). The outline's condition, being continuous or incomplete, is therefore a glyph element that significantly separates month signs from day signs $\left(n_{11}=57, n_{12}=18 ; n_{21}=7, n_{22}=214\right.$, Chi-square 171.01, $\left.\mathrm{p}<0.001\right)$. But on the other hand, the assertion 
that the outline of month signs may reflect the roundish wall of a log beehive in cross section, as it is supposed to do in day signs, does not seem so self-evident. However, there is a technique that some current Mayan beekeepers apply in order to gain temporary access to the centrally located brood section of a nest without having to remove the bees' food storage pots first. They do this by splicing open the $\log$ lengthwise (Figure 6a) in a way that preserves the log's overall structure. This act of restrained fracturing creates a horizontal slit just large enough to detach one or more of the nest's brood combs and easily take them out as a whole. The resulting fissure is small enough to allow the beekeeper to easily reinstate the log's original shape and function, and thus enables the colony to recover. It is the condition that arises from the lengthwise opening of the bee nest's wooden enclosure that makes that its cross section closely matches the discontinued outer frame of month signs (Figure 6b). The same apparent congruence indirectly reveals that the lengthwise opening of log hives probably was a regular method that Mayas from the Classic period have been using to increase colony numbers in an ecologically sustainable way (see TERREMATE and KOEDAM, in prep).

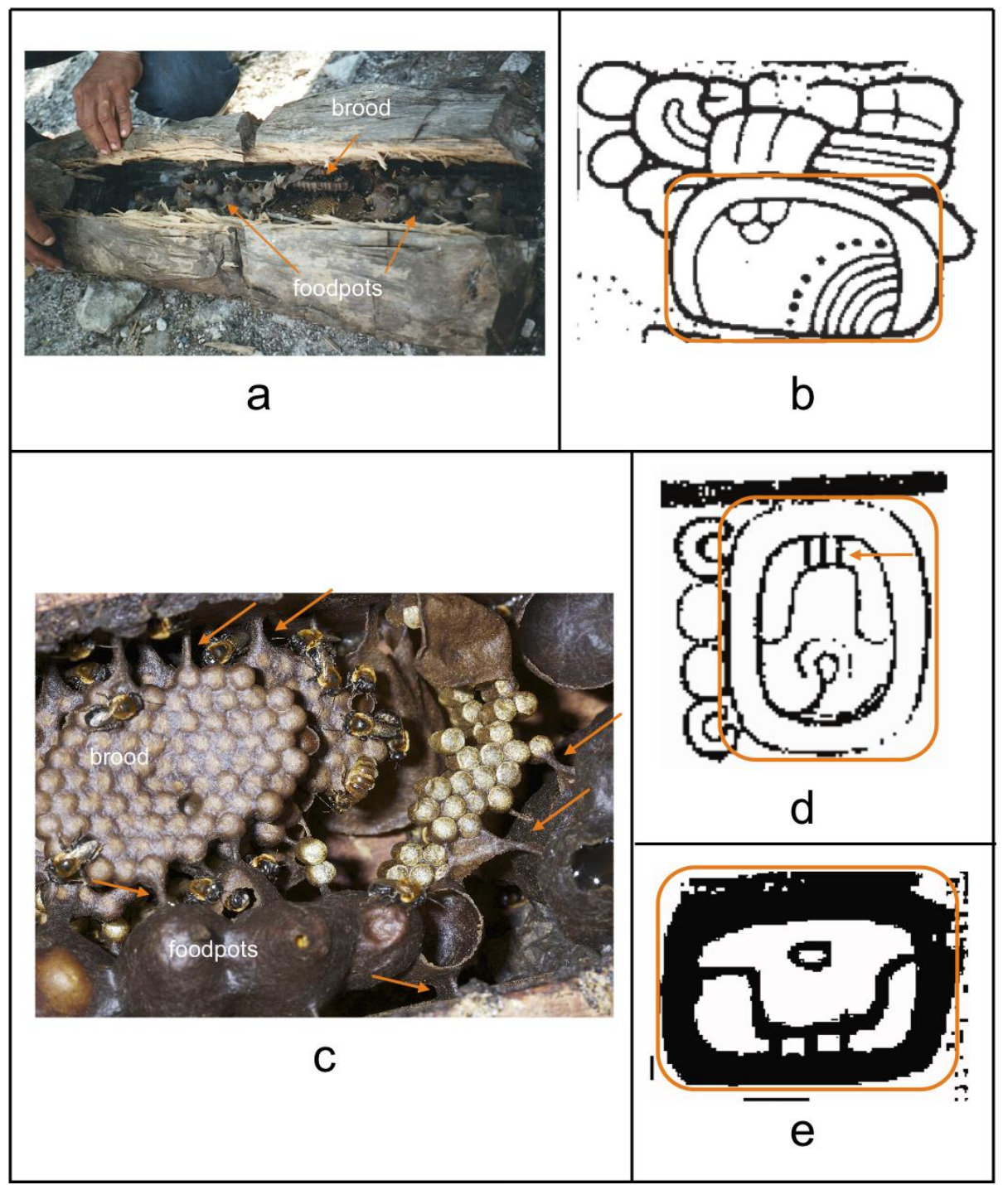

Figure 6: a. View of a partially exposed Melipona beecheii nest in a trunk that was sliced open lengthwise with the intention to remove some of the nest's brood combs, leaving food pots on the left and right side untouched (photo courtesy of Marilda Cortopassi-Laurino), b. A sign related to the Kawak-like month Sak (orange sector), showing the interrupted nature of its outline which is a characteristic of many month signs (see also Figure 3c), Tikal Stela 31, back side (STUART, 2011), c. Top view of a Melipona (M. subnitida) nest to show the short, waxen pillars and ribs (arrows) that connect the brood with food pots and these structures with the inner part of the rigid wall of the nest box, irrespective of whether the nest box is rectangular, as this photo, or is round shaped, $\mathrm{d}$. The day sign $\mathrm{Kib}^{\prime}$ (orange sector) with the short vertical lines (arrow), Palenque temple of the foliated cross, right hand slab of the inscribed panel (MAUDSLAY, 1889-1902), e. The day sign $K$ 'an (orange sector), Madrid Codex, p. 103

Whatever the view on the model of origin of the month signs' lay out, the fact that the interior 
design of the day sign Kawak is also the main element of four different month signs may reflect the functional relevance of honey in ancient Maya society. The value of honey for the Mayas to a large extent draws from its use in the brewing of the ceremonial drink balche (LANDA, 1566; see VAIL, 1994). This societal interest may be comparable to the social and religious applications of alcoholic beverages by Neolithic communities in the Near East (see DIETRICH et al., 2012; LIU et al., 2018).

\section{Why did Mayan beekeepers need written figures in the first place?}

Ancient Egyptian beekeepers of Apis mellifera lamarckii (Hymenoptera, Apini) used a method of stacking many horizontal pipe hives in fixed positions (CRANE, 1983). This may have created even larger concentrations of hives per locality than in the case of the ancient Mayas. Still, the large sizes that meliponaries in ancient Maya beekeeping reached in some places (see JONES, 2013) may have been unique. In spite of the recognized incidences of traditional bee husbandry on a large scale by the Egyptians as well as by the Mayas, the ways that these pre-modern types of beekeeping were managed is a largely unexplored area of research with little information available.

The here-in suggested conversion of various beekeeping-related elements into figures for documentation in itself does not explain the circumstances and motives that caused Mayan beekeepers to initiate some sort of annotation system. In my view, beehive cross-section-based day signs probably originated from a system of written, mnemonic figures related to various aspects of beekeeping. Such systems were needed to improve the management of the bees when this agricultural activity increased in scale and thus became more complex in its organization. Managing and working in meliponaries with numerous, adjacent hives requires different management skills, and this could have been especially relevant for a native bee such as $M$. beecheii kept in logs that were similar in appearance. Albeit the five day signs apparently have a pictorial resemblance to details of beekeeping, it would be premature to discuss for each of these glyphs what specific information about beekeeping practice it helped to memorize and what specific message it tried to convey.

\subsection{A general need to monitor hived stingless bee colonies}

Although stingless bee nests are perennial (SLAA, 2006), their growth and developmental cycles are intimately related to seasonal rainfall and the consequent flowering of the majority of plants (ROUBIK, 1989). Therefore, major hive handling tasks such as reaping honey and artificially multiplying colonies are mainly seasonally determined (e.g. JONG, 1999; GONZÁLEZ-ACERETO, 2008). Some of the so-called bee almanacs of the Madrid Codex seem to closely parallel the seasonal pattern of the various activities that are associated with Maya beekeeping as it still is practiced today (VAIL, 1994). In between periods of beekeeping manipulations, colony conditions change, not only as an outcome of previous invasive manipulations, but also due to, for instance, severe weather phenomena, such as tropical storms (JÁUREGUI, 2003; MEDINA-ELIZALDE et al., 2016) and droughts (e.g. HOGGARTH et al., 2016), or as a result of occasional attacks by natural enemies. Throughout the year, therefore, ancient Mayan beekeepers must have kept a vigilant eye to make sure the maintenance and growth of their colonies was assured.

Colonies of Melipona bees, including the Mayas' $M$. beecheii, are generally much smaller and more vulnerable than Apis colonies; several other aspects of the biology of stingless bees differ from those of Apis honey bees as well (ROUBIK, 1989). Overall, this means that stingless bee husbandry or meliponiculture differs from apiculture. For instance, in stingless bees the presence of an active queen and the number of bees per colony as factors contributing to colony survival are relatively more important. This means, among other things, that stingless-bee keepers should be worried about the ability of colonies to defend themselves against natural enemies. It is obvious that such a concern becomes even more pressing when certain colonies for some reason are already weak.

Colony population size, queen age and the brood and food stocks are the main elements that make bee colonies differ one from each other. Small genetic differences should furthermore contribute to variations in colony performance, although the extent to which genetic variation determines colony character and condition has yet to be investigated for stingless bees (see for Apis honey bees: ROBINSON and PAGE, 1988; 1989). Overall, natural, inter-colonial differences in these relatively 
small colonies should make the need for inspections on a regular basis even more urgent. Therefore, it is not only the manipulating and opening of rustic hives with stingless bees that should be restricted to a minimum as was mentioned earlier. Regular monitoring of stingless bee colonies and, if the occasion arises, intervention and necessary readjustments in general seems much more necessary than in apiculture as well (but see REDFIELD and VILLA ROJAS, 1934). Coincidently, the task of monitoring is easy to perform as stingless-bee hives generally are kept near human settlements.

\subsection{From small to more extensive beekeeping}

The principal reason for beekeeping on a larger scale is that it would enable greater production of honey and wax. In some cases pre-Hispanic Mayan beekeepers were able to aggregate large numbers of hives, literally stockpiling them, in simple shelters with a thatched roof (see KENT, 1984; GONZÁLEZ-ACERETO, 2012). No such huge aggregations exist anymore (VILLANUEVA et al., 2005).

To boost production, beekeepers prefer to focus on colonies that are of special interest; these could fall under one of two different selection criteria. One criterion for a need for special attention would involve those colonies that for some reason lag behind in development and need help before their condition deteriorates so much that it becomes unviable. Alternatively, a beekeeper could concentrate on those colonies that perform above average in order to use them in future multiplication events. Whether any Mayan beekeepers applied the latter kind of selection procedure intentionally is unknown.

Experience shows that in meliponiculture the production of honey and wax with a small number of hives is easy to operate by a single person at almost any time (see NOGUEIRA-NETO, 1997). Whenever beekeeping enterprises grow larger, adaptations in their organization become essential. Some of these adaptations concern features of human endeavor in general, while others deal with the interaction of the bees with their natural environment when their colonies are grouped by man. Below I list two issues related to bee ecology that can be considered of minor importance to beekeepers with only a few hives, because they are controllable without much effort. However, whenever beekeepers create large assemblies of hives, these same issues become relevant in ways that if no suitable actions are taken, they can turn into potentially disruptive events.

\subsection{Many hives concentrated; particular consequences for bee management}

As a consequence of having large hive concentrations, the frequency of parasite and predator attacks would have increased. Moreover, such hive aggregations would also have augmented the scale of eventual interspecific assaults on colonies within the bee shed and consequently made such events an even heavier burden. Mayan beekeepers with many hives, therefore, would have stepped up the monitoring of their hives. They also should have adopted pre-emptive measures that could mitigate these and other potentially colony-lethal dangers. It must have been essential for any such beekeeper to be able to quickly recognize and afterwards monitor colonies that have a greater than normal susceptibility to external threats. These can be colonies resulting from recent splitting processes, colonies that for some reason have recently experienced intrusive manipulation and those that have survived an attack of a natural enemy and are in the process of recovering. An ant attack or a phorid fly infestation in these already weak colonies is one of the worst things that can happen. As a consequence, beekeepers with many hives should have removed colonies under phorid fly assault from the shed, especially when their condition reached beyond the point of being able to make them normal again. In this respect, empty, bee-abandoned hives could likewise be considered as "bad apples" that beekeepers must remove to maintain the health of their bee stock.

Another preoccupation for beekeepers when raising bees in large hive assemblies is colony nourishment. In social bees, stored food serves to bridge periods of shortage in nectar and pollen sources (MICHENER, 1974). The harvest of any bee material from nest interiors is therefore restricted by the fact that for a colony to perpetuate, worker bees need a minimum amount of resources, including brood. Based on experience, ancient Mayan beekeepers would always have left a fraction of a nest's food reserves untouched; otherwise it could starve. The existence of this working method among traditional Mayan beekeepers was confirmed by REDFIELD and VILLA ROJAS (1934). 
In feral nests, a bee's access to food is ecologically regulated by colony consumption, the amount in storage, and the volume collected from flowers by forager bees. Below a necessary minimum amount of foraged food, colony maintenance is at risk. When, for instance, the concentration of hives goes up and so more bees visit the local flower patches, the threshold of the carrying capacity of a hive's surrounding environment can be surpassed (e.g. ELTZ et al., 2002; AL-GHAMDI et al., 2016). As a consequence of this local depletion in food available to bees, the intake of nectar and pollen per colony decreases and even may result in serious malnutrition. With a large concentration of hives, the pressure on both a beekeeper and his bees due to a shortage of wild flowers because of normal seasonal changes can suddenly become critical. To make things worse, small, weak colonies may suffer from intraspecific robbing by bees from stronger, neighboring colonies hived nearby when food is sparse (NOGUEIRANETO, 1997).

What measures ancient Mayan beekeepers applied to moderate or avoid the above presented examples of food scarcity and colony malnutrition is largely unknown. Work of VAIL (1994) on the Madrid Codex bee almanacs mentions the possibility of Mayan beekeepers transporting their hives to places with better food plant resources to ease this problem. On the other hand, CAPPAS E SOUSA (1996) infers from some pictures of the same document that Mayan beekeepers had the ability to recognize colonies dealing with food shortages and to nourish these artificially to overcome this problem.

\subsection{Coping with complexity via hive identification and record keeping}

The above considerations makes it clear that the artificial conditions created by aggregating large numbers of hives must have amplified the effects of certain ecological interactions of bees in a way that would have posed new challenges for those that took care of them. An overarching problem, and of major significance for this study, must have arisen when large-scale Mayan beekeepers needed to assure the ability to accurately pick out a colony with special needs or qualities among the many present. They also needed to remember the reasons to keep following a specific colony.

In a limited but overall manner, the identification of log hives is always possible due to an inherent outcome of a handling phase as part of traditional beekeeping; a log hive that recently has been resealed can, in principal, be identified during the next few days due to the discoloration of the drying mud mortar that was used to seal the log hive ends. In case of the use of so-named A-frame racks, the recognition of recently manipulated hives would likely have been done per queue of stockpiled hives (see KOEDAM, in prep). In this respect, the Mayan use of these inclined support structures to stock log hives at high densities in an efficient manner could have had other effects on beekeeping administration and glyph development, and is therefore discussed elsewhere in detail (KOEDAM, in prep). It should be emphasized that marks of recent, manual restoration of the opened ends of hives with mud mortar neither offer invariably unambiguous clues to differentiate between hives nor are such clues obvious for periods longer than a couple of days.

Although no log hive is ever completely similar on its outside to that of another one, such differences do not rule out that beekeepers occasionally would have confounded one hive with another. One of the main problems with large aggregations of homomorphic hives is that the mistakes in identification of individual hives must have become a serious limiting factor to Maya beekeeping efficiency and success. With increasing numbers of hives in a bee shelter, the chances that a beekeeper would not have remembered exactly which colonies needed attention among the many he has placed together would have increased. Identification errors would have deprived colonies from receiving adequate attention and remedy. Other mistakes would have been the unnecessarily opening of hives, or even the inadvisable harvesting of honey from colonies that, for instance, were in the midst of a process of recovery.

Whatever colony a beekeeper is looking for, at larger scales he would be able to identify a specific hive only via the implementation of some kind of system of mnemonic designs or lasting symbols. The register of and ready access to facts about the life history of such a colony, to know the reason why it should be specially handled at any given moment, would be subject to the same demand in mnemonic durability and retrievability. For instance, when colonies resulted from artificial 
multiplication processes, the custom of record keeping would have enabled Mayan beekeepers to accompany the development of these and other colonies involved so as to improve their chances of survival. The need for such a follow-up system for newly created colonies would have become imperative if exchange of whole colonies was part of ancient Maya trading business. However, so far evidence for this type of commerce does not exist.

Overall, extensive bee husbandry must have become special amid other Mayan practices of farming in that relying on the capacity of human memory alone would certainly no longer have sufficed. Only by the invention of a system of marking individual hives and making records of the history of the colonies they house, would Mayan beekeepers been able to strike a balance between guaranteeing high colony yields and avoiding the unnecessary opening of hives and thereby mitigating excessive stress. I therefore propose that some Mayan beekeepers with many hives implemented administrations based on written, mnemonic figures that relate to various aspects of beekeeping. Somehow, the day signs Imix, Kib', Kab'an, Kawak and Ajaw derived from these beekeeping-related figures.

A major event for any beekeeper probably was and still is the complete loss of a colony with a vacant hive as a silent reminder. Through experience, the ancient Mayas must have recognized the importance of resident queen bees for honey and wax production. The development and use of the zero glyph T173 may have been based on the perception of how permanent loss of the queen caste could derail a colony and push it to extinction (KOEDAM, 2018). Whether the creation and use of the zero glyph T173 would, similar to the precursors of day signs, have been a consequence of large concentrations of hives or arose independent of these conditions is unclear. Nevertheless, its textual uses other than that of a positional zero are apparently based on other aspects of adult queen lifecycles that affect colony maintenance and reproduction. The versatility of T173's textual function reveals a considerable knowledge of the bees' social organization, something that the Mayas could only have obtained through proficient beekeeping. In addition, the co-occurrence of T173 and beekeeping-related day signs on monuments from the Classic period stresses the antiquity of Maya beekeeping and its wide distribution. Archaeological findings of log hive stoppers (CRANE and GRAHAM, 1985) already confirmed this view.

\subsection{Sharing information with aides, and preparation}

As soon as organizational problems arising from the need for differential handling of hives in large assemblies forced some Mayan beekeepers to start recording particular hive data with the help of written, mnemonic figures, other bee management-related issues co-occurred that may have further shaped the graphical properties of these figures and their role in glyph communication. This is because under the circumstances of running a business on a larger scale, indispensable issues such as sharing of knowledge with others involved, the planning of procedural series, and preparative work each may have a part.

In the cases of beekeeping at larger scales, the amount of work to be done during periods of harvest and artificial multiplication within a restricted time frame could probably not be conducted without the organized aid of extra personnel. In principle, these aides could have been recruited from among kin as well as from non-kin, although a preference for the former would be expected due to apparently existing parallels between cultural and genetic transmission (see AUGNER, 2000). A preference for relatives as helpers would also seem more logical when, sooner or later, their role could merge into that of the true beekeeper substitute (see section 5.6).

At an early stage of hive administration, the associated annotations would have served the beekeeper himself. Yet, a considerable increase in hive numbers must have broadened the annotations' original role of just memorizing beekeeping facts and events for personal use into a function that included the sharing of this information with other people. In order to instruct aides and other individuals involved, any exchange of information should have been such that the frequency of misinterpretations about the meaning of the mnemonic figures would have been as low as possible. Therefore, the designs of mnemonic figures must have been subject to adjustments in a way that turned them into a type of communication that was not only easy to understand and use, but, above all, unambiguous. At a subsequent stage, therefore, initially private, domestic beekeeping annotations would not only circulate 
more, but also would have become increasingly visually standardized.

Procedures consist of a series of different action steps to reach a specific goal, sometimes each one of them obligatory and to be carried out with care. The time scale and organization of these working methods in beekeeping would range from short and simple to more complex ones that could extend over longer time periods. When a beekeeper owns only a few colonies, he can easily remember the steps of the different procedures and the order of those steps. A beekeeper working alone could have become more efficient as a result of the repetitive nature of procedures executed on subsequent hives under comparable conditions. When the work with bees is done in permanent conjunction with others, however, there is a need to explain and demonstrate to co-workers how a certain action should be performed. There would also be a need to explain if and how a particular action has to be obligatorily preceded or followed by another one, forming a fixed chain of tasks. In other words, a beekeeper would need to teach the persons involved procedures and their corresponding action steps so as to let their purpose clearly be understood and their order remembered. The teaching of at least the most important procedures and/or more complex ones would have been greatly facilitated, both for instructor and student, when they were somehow annotated. Possible examples of such documentation for didactic support are the bee almanacs found in the Madrid Codex (VAIL, 1994). It would be no more than a logical step for some of the earlier mentioned mnemonic figures, considering their presumed beekeeping background, of becoming inserted, in original or modified form, in such manuals.

Traditional Maya beekeeping entails the performance of rituals and ceremonies to, among other things, placate the bees and their gods, and thus assure honey revenues (WEAVER and WEAVER, 1981; VAIL, 1994; JONG, 1999). Control of and improvement in bee treatment and hive care through the involvement of hive identification and record keeping as one of the adopted administration measures must have contributed, as a by-product, to the appeasement of the gods that were supposed to watch over the bees according to ancient Maya belief. In any case, the acts of bee worshipping involved multiple persons and required preparation (see also ŹRAŁKA et al., 2018). However, extensive Maya beekeeping in itself inevitably would also have needed organizational and technical preparation, if nothing else to put a work team together and inform its participants about the timing and utensils required. For instance, in the case of a honey harvest, enough containers had to be organized to be able to collect, store and, when needed, process the prospective, large volumes of honey. Another point related to hive manipulation is that, to reseal hives without much delay, water would have to be on hand to mix it with soil for making the mud mortar. Other measures taken beforehand could have included the familiarizing of inexperienced helpers with beekeeping. In addition, Mayan beekeepers with many hives could have adopted the method of accessing the inside of at least a small sample of their hives to decide the most convenient date on which a general honey harvest should commence.

\subsection{The intrinsic socio-economic value of extensive bee husbandry}

Among the host of organizational issues characteristically emanating from the increase in size of whatever type of business, two more items are worth addressing that would have affected the use of mnemonic, beekeeping-related figures in Maya glyph communication.

Owing to their perennial character, the value of hived colonies of bees such as $M$. beecheii to the families and communities that possessed them was already emphasized elsewhere (KOEDAM, 2018). An increase in the number of hives obviously would have improved the conditions of life of the owners because this would have generated more products and trade. Still, an indirect consequence of meliponaries with lots of hives and consequently more business in valuable bee assets is that, under these circumstances, beekeeping became an ever-larger and thus inseparable part of a household's capital. Therefore, at the least the continuance of beekeeping and its revenues must have become a goal in itself in the cases where this practice was done on a larger scale. This self-organizing process of socioeconomic reinforcement and, in this case agricultural specialization would have further enhanced the effectiveness of a system of mnemonic figures as a management instrument.

When a bee business became more important to its local society, the status of the beekeeper would have risen correspondingly. In addition, his leadership and performance would be increasingly more imperative to the continuity and survival of beekeeping practice. Nevertheless, for various reasons, 
any person will someday be hindered, temporarily or permanently, from doing his regular work or practicing his profession. In the case of extensive beekeeping, a sudden lack of supervision and expertise would have become a serious threat to local commerce (see also VILLANUEVA et al., 2005). To avoid putting beekeeping business at risk by such a human resources problem, and to safeguard colonies and revenues for the families involved, owners of many hives should have been strongly encouraged to invest in official substitutes. Likely, they would have chosen someone suitable from among close kin, and then submit this person to some sort of qualifying educational program. In such a case, an instruction manual with understandable pictorial elements would have been a helpful support as part of a strategy to train beekeeper successors. The bee almanacs of the Madrid Codex (VAIL, 1994) would have been an appropriate tool to address this particular didactic need, as part of a cultural transmission from one generation to the next.

\section{FINAL CONSIDERATIONS}

Earlier work of VAIL (1994) and CAPPAS E SOUSA $(1995,1996)$ on Maya ethnohistory and ethnography reveal in what way and the degree to which the keeping of native bees and ancient Maya culture were interwoven. In line with my earlier work on glyph T173 (KOEDAM, 2018), in this current paper I show that the relationship between a part of Maya hieroglyphs and meliponiculture may have been more systemic than generally thought. I make the case that the design of at least five day signs and the configuration of nearly all variants of the 20 day signs are intimately linked to the way the Mayas kept native, stingless bees in hollowed-out logs. The five day signs, which are related to extant bee nest elements, probably originated from administrations implemented to confront the complexity of extensive beekeeping and the sharing of information thereon with aides.

With the fall of Classic Maya civilization and the subsequent Spanish invasion, knowledge about and use of glyphs must have decreased correspondingly. Whether the fall of Maya civilization together with the Spanish conquest went alongside with a reduction in the Mayas' traditional cultivation of bees is unclear (JONG, 1999). The day signs examined in this study involve attributes of beekeeping that Mayan beekeepers still deal with nowadays. However, traditional Maya beekeeping at present is in strong decline both in numbers of practitioners and in scale. Therefore, the need for the keeping of records or for whatever other kind of system of hive administration is currently almost obsolete; the physical memory of a singly operating person alone suffices, and, if needed, such a person can pass on his experience orally to a next generation supposedly with little effort.

Since humans induced major changes in the natural environment's structure and organization as a result of logging and intensive agriculture, native bees and their keeping have come under strong pressure worldwide. Besides habitat degradation and loss, a further complicating, significant effect for a large part of the American continent's ecosystems has been the introduction of exotic Apis honey bees (ROUBIK, 1982). The strong competition that Africanized honey bees exert on natural resources, such as food and nesting space, must have added to the negative effects that populations of feral indigenous bees already experience (see also GELDMANN and GONZÁLEZ-VARO, 2018; VALIDO et al., 2019). This competition must have indirectly impacted the state of stingless-bee keeping in the Americas as well. In addition, many beekeepers have abandoned meliponiculture and switched to apiculture. This is because, although beekeepers have to take special measures to minimize the inconvenience and even serious risks which Apis bee aggressiveness entails, the latter kind of beekeeping is highly profitable (QUEZADA-EUÁN et al., 2001).

Recently, the function of native bees in ecosystems, including agro-ecosystems, has been the subject of numerous studies, mainly because of their vital role in pollination (e.g. GARIBALDI et al., 2014; KLEIJN et al, 2016). Research on pollination ecology focuses on the various sorts of impediments of pollination that exist and how to mitigate them. Consequently, the production of seeds and fruits can be guaranteed and where necessary improved, including by means of the employment of both wild and managed bees in the pollination of crops. The above narrative about the possible origin of certain Maya day signs emphasizes that there are other powerful, non-ecosystem-service-based arguments, as in this case cultural and historical ones, to value native bees. These arguments offer extra leverage to suggest several measures, such as those proposed by VILLANUEVA et al. (2005), to value the multiple benefits 
of native bees. Among other things, what remains of traditional Maya beekeeping should receive proper attention and support. Furthermore, new, sustainable beekeeping initiatives, either traditional or modern, should be stimulated. Finally, raising general awareness of the need to conserve native bees should be encouraged, in conjunction with programs to evaluate, restore and protect the wild habitats of these bees.

\section{ACKNOWLEDGEMENTS}

The development of the ideas presented in this study happened during my appointment as a visiting professor of the Ecology and Conservation Group at the department of Animal Sciences, Universidade Federal Rural do Semi-Árido (UFERSA), Rio Grande do Norte. Camila Maia-Silva and Michael Hrncir of Abelhas no Semiárido, UFERSA, are thanked for their patient company and help. Vera L. ImperatrizFonseca, Paulo Nogueira-Neto and Marilda Cortopassi-Laurino, Universidade de São Paulo, São Paulo, and Selma Carvalho and Francisco das Chagas Carvalho, Moreilândia, Pernambuco, are appreciated for their general support and motivation during my bee research in Brazil. At Universiteit Utrecht, Nederland, Marinus J. Sommeijer, Hayo H. W. Velthuis and Jacobus C. Biesmeijer refined my observing skills as an ethologist, while Wilbert A. M. Linnemans inspired me to walk new paths in science and art. David de Jong is acknowledged for linguistic advice and anonymous reviewers for their remarks.

\section{REFERENCES}

AL-GHAMDI, A.; ADGABA, N.; GETACHEW, A.; TADESSE, Y. New approach for determination of an optimum honeybee colony's carrying capacity based on productivity and nectar secretion potential of bee forage species. Saudi Journal of Biological Sciences, v. 23, p. 92-100, 2016.

AUNGER, R. The Life History of Culture Learning in a Face-to-Face Society. Ethos, v. 28, n. 3, p. 445-481, 2000.

AYALA, R. Revision de las abejas sin aguijón de Mexico (Hymenoptera: Apidae: Meliponini). Folia Entomológica Mexicana, v. 106, p. 1-123, 1999.

BIESMEIJER, J. C. The organisation of foraging in stingless bees of the genus Melipona: an individualoriented approach. 1997. 263 p. Doctoral thesis, Utrecht University, The Netherlands.

BIESMEIJER, J. C.; GIURFA, M.; KOEDAM, D.; POTTS, S. G.; JOEL, D. M.; DAFNI, A. Convergent evolution: floral guides, stingless bee nest entrances, and insectivorous pitchers. Naturwissenschaften, v. 92, p. 444-450, 2005.

BIESMEIJER, J. C.; SLAA, E. J.; KOEDAM, D. How stingless bees solve traffic jams. Entomologische Berichten, v. 67, n. 1-2, p. 7-13, 2007.

BLUME, A. Maya concepts of zero. Proceedings of the American Philosophical Society, v. 155, n. 1, p. 51$88,2011$.

BORROR, D. J.; DELONG, D. M.; TRIPLEHORN, C. A. An introduction to the study of insects. 4. ed. New York: Holt, Rinehart and Winston, 1976. 852 p.

BRINTON, D. G. The native calendar of Central America and Mexico. A study in linguistics and symbolism.

Proceedings of the American Philosophical Society, v. 31, n. 142, p. 258-314, 1893.

BRINTON, D. G. A primer of Mayan hieroglyphs. Series in Philology, Literature and Archaeology, v. 3, n. 2, p. 9-152, 1894.

CAPPAS E SOUSA, J. P. A. meliponicultura Maia (O jaguar abelha e os deuses Maias). O Apicultor, v. 4, p. 17-19, 1996.

CAPPAS E SOUSA, J. P. Os Maias e a meliponicultura. O Apicultor, v. 3, p. 15-17, 1995.

CASTRO AGUILAR, P. Reivindicacion de la Melipona. CHAPMAN, J. L.; REISS, M. J. (eds.), Mérida: Talleres Gráficos del Sudeste, 1971.

COHN, D. Xunan Kab, the stingless bees of the Yucatan: preserving meliponiculture in Mayan communities (Part 2). American Bee Journal, v. 145, p. 724-728, 2005.

CONTRERA, F. A. L.; VENTURIERI, G. C. Revisão das interações entre forídeos (Diptera: Phoridae) e abelhas indígenas sem ferrão (Apidae: Meliponini), e técnicas de controle. In: JONG, D. DE; FRANCOY, T. M.; SANTANA, W. C. (eds.), Anais do VIII Encontro sobre Abelhas, Brasil, São Paulo, Riberão Preto, 2008. p. 146-153.

CORTOPASSI-LAURINO, M.; IMPERATRIZ-FONSECA, V. L.; ROUBIK, D. W.; DOLLIN, A.; HEARD, T.; AGUILAR, I.; VENTURIERI, G. C.; EARDLEY, C.; NOGUEIRA-NETO, P. Global meliponiculture: challenges and opportunities. Apidologie, v. 37, p. 275-292, 2006. 
COUVILlON, M. J.; WENSELEERS, T.; IMPERATRIZ-FONSECA, V. L.; NOGUEIRA-NETO, P.; F. L. W. RATNIEKS, F. L. W. Comparative study in stingless bees (Meliponini) demonstrates that nest entrance size predicts traffic and defensivity. Journal of Evolutionary Biology, v. 21, p. 194-201, 2007.

CRANE, E. The archaeology of beekeeping. New York: Cornell University Press, 1983. 360 p.

CRANE, E. Amerindian honeyhunting and hive beekeeping. Acta Americana, v. 6, n. 1, p. 5-18, 1998.

CRANE, E.; GRAHAM, A. J. Bee hives of the ancient world 2. Bee World, v. 66, p. 148-170, 1985.

DIETRICH, O.; HEUN, M.; NOTROFF, J.; SCHMIDT, K.; ZARNKOW, M. The role of cult and feasting in the emergence of Neolithic communities. New evidence from Göbekli Tepe, south-eastern Turkey. Antiquity, v. 86, p. 674-695, 2012.

ELTZ, T.; CARSTEN, A.; BRÜHL, C. A.; KAARS, S. VAN DER; LINSENMAIR, K. E. Determinants of stingless bee nest density in lowland dipterocarp forests of Sabah, Malaysia. Oecologia, v. 131, p. 27-34, 2002.

GARIBALDI, L. A.; CARVALHEIRO, L. G.; LEONHARDT, S. D.; AIZEN, M. A.; BLAAUW, B. R.; ISAACS, R.; KUHLMANN, M.; KLEIJN, D.; KLEIN, A. M.; KREMEN, C.; MORANDIN, L.; SCHEPER, J.; WINFREE, R. From research to action: enhancing crop yield through wild pollinators. Frontiers in Ecology and Environment, v. 12, n. 8, p. 439-447, 2014.

GELDMANN, J.; GONZÁLEZ-VARO, J. P. Conserving honey bees does not help wildlife. Science, v. 359, n. 6374, p. 392-393, 2018.

GONZÁLEZ-ACERETO, J. Á. Cría y manejo de abejas natives sin aguijón en México. México, Yucatán, Mérida: Universidad Autónoma deYucatán, 2008. 165 p.

GONZÁLEZ-ACERETO, J. A. La importancia de la meliponicultura en México, con énfasis en la Península de Yucatán. Bioagrociencias, v. 5, n. 1, p. 34-41, 2012.

GORDON, D. M. Dynamics of task switching in harvester ants. Animal Behaviour, v. 38, p. 194-204, 1989.

HAMMOND, N.; PRING, D.; BERGER, R.; SWITSUR, V. R.; WARD, A. P. Radiocarbon chronology for early Maya occupation at Cuello, Belize. Nature, v. 260, p. 579-581, 1976.

HOGGARTH, J. A.; BREITENBACH, S. F. M.; CULlETON, B. J.; EBERT, C. E.; MASSON, M. A., KENNETT, D. J. The political collapse of Chichén Itzá in climatic and cultural context. Global and Planetary Change, v. 138, p. 25-42, 2016.

HUBER, P. Notice sur la mélipone domestique, abeille domestique mexicaine. Mémoires de la Société de

Physique et d'Histoire Naturelle de Genévé, v. 8, n. 1, p. 1-26, 1839.

INOUE, T.; SAKAGAMI, S. F.; SALMAH S.; YAMANE, S. The process of colony multiplication in the Sumatran stingless bee Trigona (Tetragonula) laeviceps. Biotropica, v. 16, p. 100-111, 1984.

JÁUREGUI, J. Climatology of landfalling hurricanes and tropical storms in Mexico. Atmósfera, v. 16, p. 193204, 2003

JOHNSON, B. R. Reallocation of labor in honeybee colonies during heat stress: the relative roles of task switching and the activation of reserve labor. Behavioral Ecology and Sociobiology, v. 51, n. 2, p. 188-196, 2002.

JONES, R. Stingless bees: a historical perspective. In: VIT, P.; PEDRO, S. R. M.; ROUBIK, D. W. (eds.), Pot-Honey: A legacy of stingless bees. New York: Springer, Part II, n. 14, Stingless Bees in Culture, Traditions and Environment, p. 219-227, 2013. doi: 10.1007/978-1-4614-4960-7.

JONG, H. J. DE. The land of corn and honey: the keeping of stingless bees (meliponiculture) in the ethnoecological environment of Yucatan (Mexico) and El Salvador. 1999. 423 p. Doctoral Dissertation, Utrecht University, Utrecht, the Netherlands.

KENT, R. B. Mesoamerican stingless beekeeping. Journal of Cultural Geography, v. 4, p. 14-28, 1984.

KETTUNEN, H.; HELMKE, C. Introduction to Maya hieroglyphs. Workshop Handbook, 10th European Maya Conference, December 5-10, Leiden: Wayeb, Leiden University, 2005.

KLEIN, D. et al. Delivery of crop pollination services is an insufficient argument for wild pollinator conservation. Nature Communications, v. 6, n. 7414, 2015. doi: 10.1038/ncomms8414

KOEDAM, D. From null size to numerical digit: the beheaded queen bee as a model for the Mayan zero glyph T173, explained through beekeeping. Ethnoscientia, v. 3, 2018. doi: 10.22276/ethnoscientia.v3i0.114

LANDA, D. DE. Yucatan before and after the conquest. Translated by W. Gates, with notes, original Spanish text first written in 1566. 2. ed. New York: Dover Publications Incorporated, 1937. 142 p.

LENTZ, D. L. Plant resources of the ancient Maya: the paleoethnobotanical evidence. In: WHITE, C. D., (ed.), Reconstructing ancient Maya diet. Salt Lake City: The University of Utah Press, p. 3-18, 1999.

LIU, L.; WANG, J.; ROSENBERG, D.; ZHAO, H.; LENGYEL, G.; NADEL, D. Fermented beverage and food storage in 13,000 y-old stone mortars at Raqefet Cave, Israel: Investigating Natufian ritual feasting. Journal of Archaeological Science: Reports, v. 21, p. 783-793, 2018.

LUCAS DE OLIVEIRA, B. Mudas ontogenéticas em larvas de Melipona nigra schencki Gribodo. Boletim 
da Universidade do Paraná. Zoologia, v. 2, p. 1-16, 1960.

MAIA, U. M.; JAFFÉ, R.; CARVALHO, A. T.; IMPERATRIZ-FONSECA, V. L. Meliponicultura no Rio

Grande do Norte. Revista Brasileira de Medicina e Veterinária, v. 37, n. 4, p. 327-333, 2015.

MALMSTROM, V. H. Origin of the Mesoamerican 260-day calendar. Science, v. 181, p. 939-941, 1973.

MARTÍNEZ, G. C. E. Ah Muzen Cab, el dios Maya de las abejas. Apicultores de Yucatán, v. 1, p. 5-6, 1938.

MAUDSLAY, A. P. Biologia Centrali-Americana; contributions to the knowledge of the fauna and flora

of Mexico and Central America. In: GOODMAN, F. D.; SALVIN, O. (Eds.), Archaeology. London: Porter,

Dulau \& Company, 1889-1902. v. I.

MEDINA-ELIZALDE, M.; POLANCO-MARTÍNEZ, J. M.; LASES-HERNÁNDEZ, F.; BRADLEY, R.;

BURNS, S. Testing the "tropical storm" hypothesis of Yucatan Peninsula climate variability during the Maya

Terminal Classic Period. Quaternary Research, v. 86, p. 111-119, 2016.

MICHENER, C. D. Bees of the world. Baltimore: The Johns Hopkins University Press, 2000. 913 p.

MICHENER, C. D. The social behavior of the bees: a comparative study. Massachusetts, Cambridge:

Belknap University Press Harvard University Press, 1974. 404 p.

MORLEY, S. G. An introduction to the study of the Maya hieroglyphs. Smithsonian Institution Bureau of

American Ethnology Bulletin, v. 57, p. 1-284, 1915.

NOGUEIRA-NETO, P. Vida e criação de abelhas indígenas sem ferrão. Editora Nogueirapis. 1997. 445 p.

OLIVEIRA, A. P. M. DE; VENTURIERI, G. C.; CONTRERA, F. A. L. Body size variation, abundance and

control techniques of Pseudohypocera kerteszi, a plague of stingless bee keeping. Bulletin of Insectology, v. 66, n. 2, p. 203-208, 2013.

OVIEDO Y VALDÉS, G. F. DE. Historia general y natural de las Indias, islas y tierra-firme del Mar

Océano. In: RIOS, J. A. DE LOS (Ed.), Madrid: Real Academia de la Historia, Original edition from 1535. v. 3 , n. 2, 1851-1853.

PIERROT, L. M.; SCHLINDWEIN, C. Variation in daily flight activity and foraging patterns in colonies of uruçu - Melipona scutellaris Latreille (Apidae, Meliponini). Revista Brasileira de Zoologia, v. 20, n. 4, p. 565$571,2003$.

QUEZADA-EUÁN, J. J. G.; MAY-ITZÁ, W. DE J.; GONZÁLEZ-ACERETO. J. A. Meliponiculture in

Mexico: problems and perspective for development. Bee World, v. 82, n. 4, p. 160-167, 2001.

REDFIELD, R.; VILLA ROJAS, A. Chan Kom: a Maya village. Washington, D. C.: Carnegie Institution of

Washington, n. 448, 1934. 236 p.

ROBINSON, G. E.; PAGE, JR., R. E. Genetic determination of guarding and undertaking in honeybee colonies. Nature, v. 333, p. 356-358, 1988.

ROBINSON, G. E.; PAGE, JR., R. E. Genetic Determination of Nectar Foraging, Pollen Foraging, and Nest-

Site Scouting in Honey Bee Colonies. Behavioral Ecology and Sociobiology, v. 24, n. 5, p. 317-323, 1989.

ROUBIK, D. W. Ecological impact of africanized honeybees on native tropical pollinators. In: JAISSON, P.

(Ed.), Social insects in the tropics. France, Paris: Université Paris-Nord, p. 233-247, 1982.

ROUBIK, D. W. Ecology and natural history of tropical bees. Cambridge: Cambridge University Press,

$1989.514 \mathrm{p}$

ROUBIK, D. W. Stingless bee nesting biology. Apidologie, v. 37, p. 124-143, 2006.

SAKAGAMI, S. F. Stingless bees. In: HERMANN, H. R. (Ed.), Social insects. New York: Academic Press, 1982. v. III, p. 361-424.

SAVILLE, M. H. The goldsmith's art in ancient Mexico. Indian notes and monographs. New York: Heye

Foundation, Museum of the American Indian, p. 1-264, 1920.

SCHELE DRAWING COLLECTION. Available at: <http://ancientamericas.org/collection>. Accessed on Sept. 32018.

SCHWARZ, H. F. Stingless bees (Meliponidae) of the western hemisphere. Bulletin of the American

Museum of Natural History, v. 90, p. 1-546, 1948.

SLAA, E. J. Population dynamics of a stingless bee community in the seasonal dry lowlands of Costa Rica.

Insectes Sociaux, v. 53, p. 70-79, 2006.

ŠPOTÁK, J. Maya timeline in Uaxactun: Calendric notations on the mural paintings at structure B-XIII.

Ethnologia Actualis, v. 17, n. 1, p. 60-88, 2017.

STUART, D. Some working notes on the text of Tikal Stela 31. 2011. 9 p. Available at: <http://www.mesoweb.com/stuart/notes/Tikal.pdf> Accessed on June 272016.

THOMPSON, J. E. S. Maya hieroglyphic writing, Introduction. v. 589, Washington D. C.: Carnegie Institution of Washington. 1950. $347 \mathrm{p}$.

THOMPSON, J. E. S. A catalog of Maya hieroglyphs. The Civilization of the American Indian Series, v. 62.

Oklahoma, Norman: University of Oklahoma Press, 1962. 458 p. 
TOZZER, A. M.; Allen, G. M. Animal figures in the Maya codices. Papers of the Peabody Museum of American Archaeology and Ethnology, v. 4, p. 275-372, 1910.

VAIL, G. A commentary on the bee almanacs in Codex Madrid. In: Sosa, C.V. (ed.). Códices y documentos sobre México, Primer Simposio, Serie Historia. México, Córdoba: Instituto Nacional de Antropología e Historia, 1994. p. 37-68.

VAIL, G. Pre-hispanic Maya religion: conceptions of divinity in the Postclassic Maya codices. Ancient Mesoamerica, v. 11, p. 123-147, 2000.

VALIDO, A.; RODRÍGUEZ-RODRÍGUEZ, M. C.; JORDANO, P. Honeybees disrupt the structure and functionality of plant-pollinator networks. Scientific Reports, v. 9, n. 4711, 2019. doi: 10.1038/s41598-01941271-5

VEEN, J. W. VAN; SOMMEIJER, M. J. Colony reproduction in Tetragonisca angustula (Apidae, Meliponini). Insectes Sociaux, v. 47, p. 70-75, 2000.

VILLANUEVA, G. R.; ROUBIK, D. W.; COLLI-UCÁN, W. Extinction of Melipona beecheii and traditional beekeeping in the Yucatán peninsula. Bee World, v. 86, n. 2, p. 35-41, 2005.

WEAVER, N.; WEAVER, E. C. Beekeeping with the stingless bee Melipona beecheii, by the Yucatecan Maya. Bee World, v. 62, n. 1, p. 7-19, 1981.

ŹRAŁKA, J; HELMKE, C.; SOTELO, L.; KOSZKUL, W. The discovery of a beehive and the identification of apiaries among the ancient Maya. Latin American Antiquity, v. 29, n. 3, p. 514-531, 2018. doi: 10.1017/laq.2018.21 